\title{
Two new aurachins from Rhodococcus sp. Acta 2259*
}

\author{
Jonny Nachtigall ${ }^{1}$, Kathrin Schneider ${ }^{1}$, Graeme Nicholson ${ }^{2}$, Michael Goodfellow ${ }^{3}$, Heidi Zinecker ${ }^{4}$, \\ Johannes F Imhoff ${ }^{4}$, Roderich D Süssmuth ${ }^{1}$ and Hans-Peter Fiedler ${ }^{5}$
}

The Journal of Antibiotics (2010) 63, 567-569; doi:10.1038/ja.2010.79; published online 7 July 2010

Keywords: aurachins; glycogen synthase kinase 3-beta inhibitors; Rhodococcus; structure elucidation

In the course of our HPLC screening program, we investigated freshly isolated actinomycete strains from selected terrestrial and limnetic habitats with the aim of detecting novel drugs for pharmaceutical applications. The strains were grown in submerged culture in different media, and extracts prepared from mycelia and culture filtrates at various fermentation times. The metabolite patterns of the strains were analyzed by HPLC-diode array monitoring (HP 1090; Agilent, Waldbronn, Germany) in combination with our in-house HPLC-UVvisible database. $^{2}$ Strain Acta 2259 was of special interest because of the presence of a prominent peak in the mycelium extract at a retention time of $12.9 \mathrm{~min}$ in our standardized gradient elution profile (Figure 1). It also showed an unusual UV-visible spectrum that differed from those of 933 reference compounds stored in our HPLC-UV-visible database. During the isolation and purification procedure, it became obvious that compounds $\mathbf{1 - 4}$ co-eluted in the same peak at a retention time of $12.9 \mathrm{~min}$.

Strain Acta 2259 was isolated from activated sludge foam collected at Milcote Pilot Sewage Treatment Plant, Stratford-upon-Avon, UK. The strain was examined for a number of key properties known to be of value in Rhodococcus systematics. ${ }^{3}$ Thus, it grew well on yeast extract-malt extract agar (ISP medium 2) producing creamy colonies and gave whole-organism hydrolysates that were rich in meso-diaminopimelic acid and in mycolic acids. Menaquinones having two of the eight isoprene units hydrogenated, $\mathrm{MK}-8\left(\mathrm{H}_{2}\right)$, were the predominant isoprenologs. Sequencing the complete $16 \mathrm{~S}$ rRNA gene led to a similarity of $99.8 \%$ with $R$. baikonurensis (AB071951), 99.2\% with R. erythropolis (X81929) and 99.0\% with R. globerulus (X80619), respectively, which are the nearest phylogenetic neighbors to strain Acta 2259.

Batch fermentations of strain Acta 2259 were carried out in a 201 fermentor equipped with a turbine impeller system (Biostat b20; B. Braun, Melsungen, Germany) in a medium consisting of soluble starch $10 \mathrm{~g}$, glucose $10 \mathrm{~g}$, glycerol $10 \mathrm{~g}$, corn steep powder $2.5 \mathrm{~g}$
(Marcor, Hackensack, NJ, USA), Bacto peptone $5 \mathrm{~g}$, yeast extract $2 \mathrm{~g}$ and $\mathrm{NaCl} 1 \mathrm{~g}$ in 11 tap water; the $\mathrm{pH}$ was adjusted to 7.3 before sterilization. The fermentor was inoculated with $5 \%$ by volume of shake flask cultures grown in the same medium at $27^{\circ} \mathrm{C}$ in $500 \mathrm{ml}$ Erlenmeyer flasks with a single baffle for $48 \mathrm{~h}$ on a rotary shaker at 120 r.p.m. The fermentation was carried out for $48 \mathrm{~h}$ with an aeration rate of 0.5 volume air/ volume/min and agitation at 1000 r.p.m. Production of compounds 1-4 started at about $20 \mathrm{~h}$ and reached a maximal yield of $394 \mathrm{mg} \mathrm{l}^{-1}$ after an incubation period of $48 \mathrm{~h}$. Compounds 1-4 were isolated from the mycelium by extraction with $\mathrm{Me}_{2} \mathrm{CO}$. After concentration to an aqueous residue, 1-4 were re-extracted by ethyl acetate and separated by column chromatography on Florisil (E Merck, Darmstadt, Germany) with $\mathrm{CH}_{2} \mathrm{Cl}_{2}-\mathrm{MeOH}$ (50:1) to give $180 \mathrm{mg}$ of $\mathbf{1 - 4}$ containing fractions. Separation of 1-4 into single compounds was achieved by semi-preparative reversed-phase HPLC on Grom-Sil 300 ODS-5 $(250 \times 20 \mathrm{~mm}, 10 \mu \mathrm{m}$; Alltech-Grom, Rottenburg, Germany) and linear gradient elution $\mathrm{H}_{2} \mathrm{O}-\mathrm{CH}_{3} \mathrm{CN}$ (57-61\% $\mathrm{CH}_{3} \mathrm{CN}$ within $39 \mathrm{~min}$ ) at a flow rate of $15 \mathrm{ml} \mathrm{min}-1$. The fractions yielded 1 (1.68 mg), 2 (3.77 mg), 3 (2.23 mg) and 4 (1.59 mg).

The mass spectra derived from the HPLC-ESI-MS analysis revealed molecular masses for $1\left((\mathrm{M}+\mathrm{H})^{+}=362.4\right), 2\left((\mathrm{M}+\mathrm{H})^{+}=364.4\right), 3$ $\left((\mathrm{M}+\mathrm{H})^{+}=378.4\right)$ and $4\left((\mathrm{M}+\mathrm{H})^{+}=380.4\right)$. This led to the assumption that the differences in structure between 1,2 and 3, 4 were due to the presence or absence of double bounds, and compared to structures 1 and 2, compounds 3 and 4 might have an additional oxygen.

The structures of the compounds were fully elucidated by extensive 1D and 2D NMR analyses. The FT-ICR-MS $(\mathrm{m} / z$ 362.24777) data of 1 indicated its molecular formula to be $\mathrm{C}_{25} \mathrm{H}_{31} \mathrm{NO}$ $\left((\mathrm{M}+\mathrm{H})^{+}{ }_{\text {theor }}=362.24784 ; \Delta \mathrm{m}=0.19\right.$ p.p.m. $)$. Furthermore, the ${ }^{1} \mathrm{H}$ NMR and HSQC data of 1 showed a total of 30 carbon-attached protons, of which 5 methyl, 3 methylene and 9 methine carbons could be assigned. Inspection of the 2D-NMR data (COSY, TOCSY, HSQC and $\mathrm{HMBC}$ ) showed the structure of $\mathbf{1}$ to be a new metabolite,

${ }^{1}$ Institut für Chemie, Technische Universität Berlin, Berlin, Germany; ${ }^{2}$ Institut für Organische Chemie, Universität Tübingen, Tübingen, Germany; ${ }^{3}$ School of Biology, Newcastle University, Newcastle-upon-Tyne, UK; ${ }^{4}$ Kieler Wirkstoff-Zentrum am Leibniz-Institut für Meereswissenschaften, IFM-GEOMAR, Kiel, Germany and ${ }^{5}$ Mikrobiologisches Institut, Universität Tübingen, Tübingen, Germany

Correspondence: Professor Dr H-P Fiedler, Mikrobiologisches Institut, Universität Tübingen, Auf der Morgenstelle 28, 72076 Tübingen, Germany.

E-mail: hans-peter.fiedler@uni-tuebingen.de or Professor Dr RD Süssmuth, Institut für Chemie, Technische Universität Berlin, Straße des 17. Juni 124, 10623 Berlin, Germany. E-mail: suessmuth@chem.tu-berlin.de

*Art. no. 56 in 'Biosynthetic Capacities of Actinomycetes'. Art. no. 55: see ref 1.

Received 12 April 2010; revised 17 May 2010; accepted 10 June 2010; published online 7 July 2010 


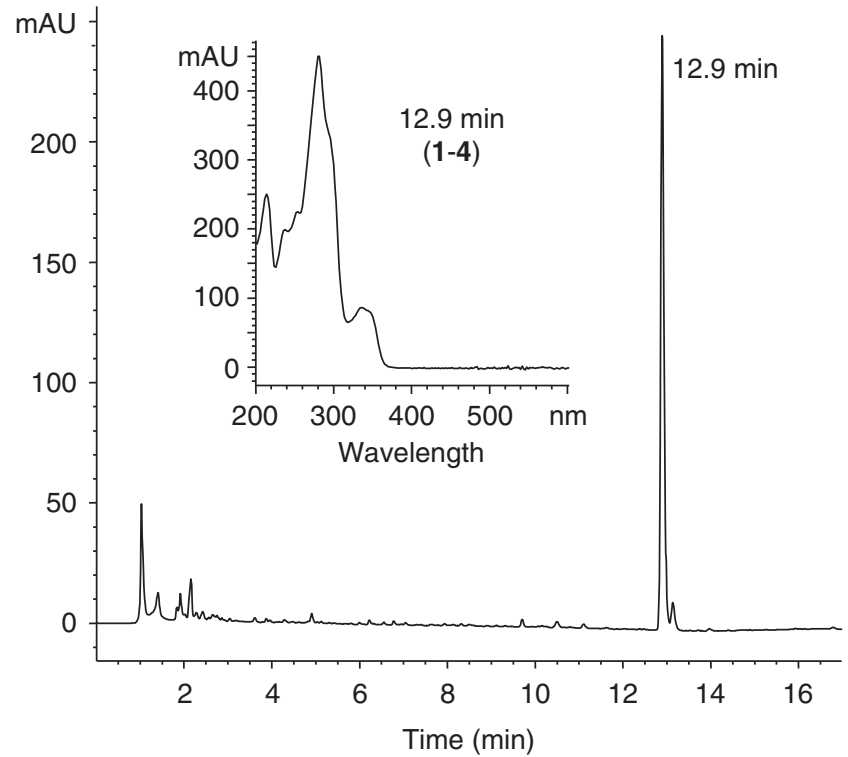

Figure $1 \mathrm{HPLC}$ analysis of a mycelium extract from Rhodococcus sp. Acta 2259 at a fermentation time of $48 \mathrm{~h}$, monitored at $260 \mathrm{~nm}$. 12.9 min=aurachins $\mathbf{1 - 4}$; inset: UV-visible spectrum of $\mathbf{1 - 4}$.
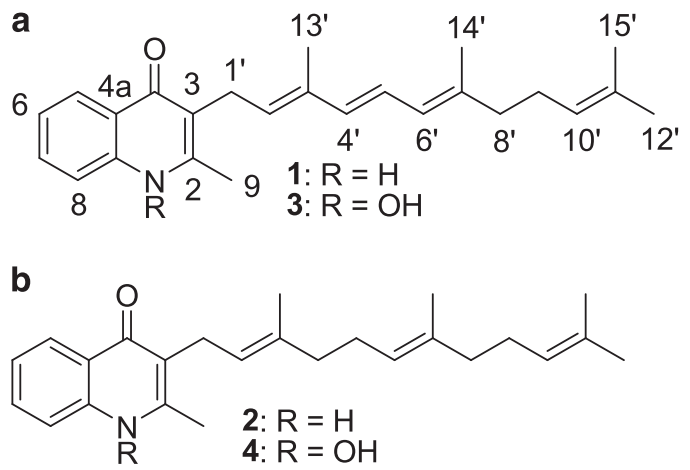

Figure 2 Structures of aurachin $Q(1)$ and $R(3)$ (a), and aurachin $D(2)$ and C (4) (b).

aurachin Q (Figure 2a). The complete NMR assignments were unambiguously carried out on the basis of COSY, TOCSY and HMBC experiments. The FT-ICR-MS $(\mathrm{m} / \mathrm{z} 378.24277)$ data of 3 indicated its molecular formula to be $\mathrm{C}_{25} \mathrm{H}_{31} \mathrm{NO}_{2}\left((\mathrm{M}+\mathrm{H})^{+}\right.$theor $=$ 378.24276; $\Delta \mathrm{m}=0.03$ p.p.m.). By comparison with the NMR data of compound 1, the structure could be assigned as its $N$-hydroxy derivative, aurachin $\mathrm{R}$ (3; Figure 2a).

The molecular formula of $\mathbf{2}$ was determined by FT-ICR-MS $(\mathrm{m} / \mathrm{z} 364.26351)$ data to be $\mathrm{C}_{25} \mathrm{H}_{33} \mathrm{NO}\left((\mathrm{M}+\mathrm{H})^{+}\right.$theor=364.26349; $\Delta \mathrm{m}=0.05$ p.p.m.). By comparison with the NMR data of compound 2 , the structure could be assigned to be aurachin D (Figure 2b). The molecular formula of 4 was established as $\mathrm{C}_{25} \mathrm{H}_{33} \mathrm{NO}_{2}$ $\left((\mathrm{M}+\mathrm{H})^{+}{ }_{\text {theor }}=380.25841 ; \Delta \mathrm{m}=0\right.$ p.p.m. $)$ on the basis of FT-ICRMS $(m / z$ 380.25841) data. By comparison of the NMR data of compound 2, the structure could be considered to be aurachin $\mathrm{C}$ (Figure 2b).

The ${ }^{1} \mathrm{H}-{ }^{1} \mathrm{H}-\mathrm{COSY}$ spectra of $\mathbf{1}$ revealed protons attached to one phenyl, one ethyl, one propenyl and one propyl moiety as shown by bold lines in Figure 3. The connectivity of these partial structures was elucidated as follows. The ${ }^{1} \mathrm{H}-{ }^{13} \mathrm{C}$-long-range couplings from the

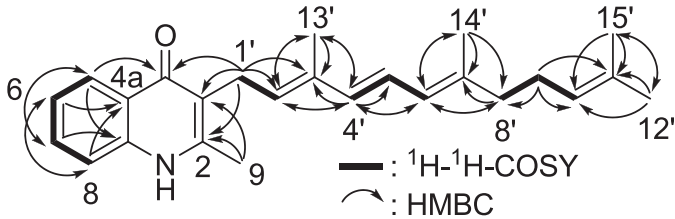

Figure 3 Key correlations in 2D NMR of 1 .

Table $1{ }^{1} \mathrm{H}$ and ${ }^{13} \mathrm{C}$ NMR spectral data of 1 in DMSO- $d_{6}$

\begin{tabular}{|c|c|c|}
\hline No. & $\delta\left({ }^{1} H\right)($ p.p.m. $) \mathrm{J}$ in $\mathrm{Hz}$ & $\delta\left({ }^{13}\right.$ C) (p.p.m.) \\
\hline 1 & - & - \\
\hline 2 & - & $147.5 \mathrm{C}$ \\
\hline 3 & - & $116.9 \mathrm{C}$ \\
\hline 4 & - & $173.5 \mathrm{C}$ \\
\hline $4 a$ & - & $123.3 \mathrm{C}$ \\
\hline 5 & $8.12 \mathrm{~d}(8.03)$ & $125.1 \mathrm{CH}$ \\
\hline 6 & 7.32 t (7.45) & $122.7 \mathrm{CH}$ \\
\hline 7 & 7.67 t (8.03) & $131.4 \mathrm{CH}$ \\
\hline 8 & $7.80 \mathrm{~d}(8.60)$ & $114.2 \mathrm{CH}$ \\
\hline $8 a$ & - & $139.4 \mathrm{C}$ \\
\hline 9 & $2.42 \mathrm{~s}$ & $14.4 \mathrm{CH}_{3}$ \\
\hline $1^{\prime}$ & $3.46 \mathrm{~d}(6.95)$ & $24.4 \mathrm{CH}_{2}$ \\
\hline $2^{\prime}$ & 5.34 t (6.95) & $130.3 \mathrm{CH}$ \\
\hline $3^{\prime}$ & - & $133.3 \mathrm{C}$ \\
\hline $4^{\prime}$ & $6.11 \mathrm{~d}(15.4)$ & $135.2 \mathrm{CH}$ \\
\hline $5^{\prime}$ & $6.31 \mathrm{dd}(15.4,10.7)$ & $122.7 \mathrm{CH}$ \\
\hline $6^{\prime}$ & $5.83 \mathrm{~d}(10.7)$ & $125.2 \mathrm{CH}$ \\
\hline $7^{\prime}$ & - & $137.2 \mathrm{C}$ \\
\hline $8^{\prime}$ & $2.05 \mathrm{~m}$ & $39.4 \mathrm{CH}_{2}$ \\
\hline $9^{\prime}$ & $2.06 \mathrm{~m}$ & $25.9 \mathrm{CH}_{2}$ \\
\hline $10^{\prime}$ & $5.05 \mathrm{t}(6.95)$ & $123.7 \mathrm{CH}$ \\
\hline $11^{\prime}$ & - & $130.7 \mathrm{C}$ \\
\hline $12^{\prime}$ & $1.63 \mathrm{~s}$ & $25.3 \mathrm{CH}_{3}$ \\
\hline $13^{\prime}$ & $1.90 \mathrm{~s}$ & $12.3 \mathrm{CH}_{3}$ \\
\hline $14^{\prime}$ & $1.76 \mathrm{~s}$ & $16.3 \mathrm{CH}_{3}$ \\
\hline $15^{\prime}$ & $1.56 \mathrm{~s}$ & $17.4 \mathrm{CH}_{3}$ \\
\hline
\end{tabular}

$1^{\prime}$-methylene protons $\left(\delta_{\mathrm{H}} 3.46\right)$ to $\mathrm{C}-3$ ( $\left.\delta_{\mathrm{C}} 116.9\right), \mathrm{C}-4\left(\delta_{\mathrm{C}} 173.5\right)$, $\mathrm{C}-2^{\prime}\left(\delta_{\mathrm{C}} 130.3\right)$ and $\mathrm{C}-3^{\prime}\left(\delta_{\mathrm{C}} 133.3\right)$ revealed the connection between the alkyl side chain and the bicyclic core moiety. The 9-methyl protons $\left(\delta_{\mathrm{H}} 2.42\right)$ coupled with $\mathrm{C}-2\left(\delta_{\mathrm{C}} 147.5\right)$ and $\mathrm{C}-3$, revealed the vicinal position to the side chain. The $2^{\prime}$-methine proton $\left(\delta_{\mathrm{H}} 5.34\right)$ showed couplings to $\mathrm{C}-13^{\prime}\left(\delta_{\mathrm{C}} 12.3\right)$ and to $\mathrm{C}-4^{\prime}\left(\delta_{\mathrm{C}} 135.2\right)$, and with the couplings of the $13^{\prime}$-methyl group $\left(\delta_{\mathrm{H}} 1.90\right)$ to $\mathrm{C}-2^{\prime}, \mathrm{C}-3^{\prime}$ and $\mathrm{C}-4^{\prime}$ the substructure of the ethyl and the propenyl moiety was determined. The coupling from the $6^{\prime}$-methine proton $\left(\delta_{\mathrm{H}} 5.83\right)$ to C-14 $4^{\prime}\left(\delta_{\mathrm{C}} 16.3\right)$ and $\mathrm{C}-8^{\prime}\left(\delta_{\mathrm{C}} 39.4\right)$, the coupling from the $14^{\prime}$-methyl group $\left(\delta_{\mathrm{H}} 1.76\right)$ to $\mathrm{C}-6^{\prime}\left(\delta_{\mathrm{C}} 125.2\right), \mathrm{C}-7^{\prime}\left(\delta_{\mathrm{C}} 137.2\right)$ and $\mathrm{C}-8^{\prime}$ and the coupling from the $8^{\prime}$-methine proton $\left(\delta_{\mathrm{H}} 2.05\right)$ to C-7' and C- $6^{\prime}$ underline the connection between the propenyl and the propyl moiety. The isopropenyl end of the alkyl side chain was determined by the coupling from $\mathrm{H}-9^{\prime}\left(\delta_{\mathrm{H}}\right.$ $2.06)$ to $\mathrm{C}-11^{\prime}\left(\delta_{\mathrm{C}} 130.7\right)$; the coupling from $\mathrm{H}-12^{\prime}\left(\delta_{\mathrm{H}} 1.63\right)$ to $\mathrm{C}-10^{\prime}$ $\left(\delta_{\mathrm{C}} 123.7\right), \mathrm{C}-11^{\prime}$ and $\mathrm{C}-15^{\prime}\left(\delta_{\mathrm{C}} 17.4\right)$; and the coupling from $\mathrm{H}-15^{\prime}$ $\left(\delta_{\mathrm{H}} 1.56\right)$ to $\mathrm{C}-10^{\prime}, \mathrm{C}-11^{\prime}$ and $\mathrm{C}-12^{\prime}\left(\delta_{\mathrm{C}} 25.3\right)$, respectively. A summary of the ${ }^{1} \mathrm{H}$ and ${ }^{13} \mathrm{C}$ NMR data of $\mathbf{1}$ and $\mathbf{3}$ is shown in Tables 1 and 2.

Comparison of the COSY spectra of $\mathbf{1}$ and $\mathbf{2}$ showed that a structural difference could only be seen at the $\mathrm{H}-4^{\prime}$ and $\mathrm{H}-5^{\prime}$ positions; 
Table $2{ }^{1} \mathrm{H}$ and ${ }^{13} \mathrm{C}$ NMR spectral data of 3 in DMSO- $d_{6}$

\begin{tabular}{|c|c|c|}
\hline No. & $\delta\left({ }^{1} H\right)($ p.p.m.) J in $\mathrm{Hz}$ & $\delta\left({ }^{13}\right.$ C) (p.p.m.) \\
\hline 1 & $11.49 \mathrm{~s}, \mathrm{br}$ & - \\
\hline 2 & - & $146.3 \mathrm{C}$ \\
\hline 3 & - & $117.1 \mathrm{C}$ \\
\hline 4 & - & $175.1 \mathrm{C}$ \\
\hline $4 a$ & - & $123.2 \mathrm{C}$ \\
\hline 5 & $8.06 \mathrm{~d}(8.10)$ & $124.9 \mathrm{CH}$ \\
\hline 6 & 7.26 t (7.70) & $122.2 \mathrm{CH}$ \\
\hline 7 & 7.58 t (8.31) & $130.9 \mathrm{CH}$ \\
\hline 8 & $7.47 \mathrm{~d}(8.31)$ & $117.3 \mathrm{CH}$ \\
\hline $8 a$ & - & $139.1 \mathrm{C}$ \\
\hline 9 & $2.35 \mathrm{~s}$ & $17.4 \mathrm{CH}_{3}$ \\
\hline $1^{\prime}$ & $3.40 \mathrm{~m}$ & $23.6 \mathrm{CH}_{2}$ \\
\hline $2^{\prime}$ & $5.37 \mathrm{t}(7.52)$ & $130.5 \mathrm{CH}$ \\
\hline $3^{\prime}$ & - & $133.1 \mathrm{C}$ \\
\hline $4^{\prime}$ & $6.10 \mathrm{~d}(15.5)$ & $135.6 \mathrm{CH}$ \\
\hline $5^{\prime}$ & $6.31 \mathrm{dd}(15.5,10.9)$ & $122.4 \mathrm{CH}$ \\
\hline $6^{\prime}$ & $5.82 \mathrm{~d}(10.9)$ & $125.1 \mathrm{CH}$ \\
\hline $7^{\prime}$ & - & $137.1 \mathrm{C}$ \\
\hline $8^{\prime}$ & 2.04 t (6.65) & $39.5 \mathrm{CH} 2$ \\
\hline $9^{\prime}$ & $2.06 \mathrm{~m}$ & $25.9 \mathrm{CH} 2$ \\
\hline $10^{\prime}$ & 5.05 t (6.17) & $123.8 \mathrm{CH}$ \\
\hline $11^{\prime}$ & - & $130.8 \mathrm{C}$ \\
\hline $12^{\prime}$ & $1.62 \mathrm{~s}$ & $25.5 \mathrm{CH}_{3}$ \\
\hline $13^{\prime}$ & $1.90 \mathrm{~s}$ & $12.1 \mathrm{CH}_{3}$ \\
\hline $14^{\prime}$ & $1.74 \mathrm{~s}$ & $16.1 \mathrm{CH}_{3}$ \\
\hline $15^{\prime}$ & $1.55 \mathrm{~s}$ & $17.5 \mathrm{CH}_{3}$ \\
\hline
\end{tabular}

these protons are methylene protons in $\mathbf{2}$ compared to methine protons in $\mathbf{1}$. The structural differences of $\mathbf{3}$ and $\mathbf{4}$ could be assigned to the $\mathrm{N}$-hydroxy derivatives of $\mathbf{1}$ and $\mathbf{2}$ due to the different ${ }^{13} \mathrm{C}$ shifts deduced from the HMBC neighboring the nitrogen atom.

Members of the aurachin family were first isolated from the myxobacterium Stigmatella aurantiaca. ${ }^{4,5}$ Recently, aurachin RE, which is similar in structure to that of aurachin $\mathrm{C}$ with a hydroxy group in position C-9' of the hydrocarbon chain was isolated from a culture broth of $R$. erythropolis JCM $6824 .{ }^{6}$ The aurachin structures are characterized by a bicyclic quinoline core system that is connected to an isoprenoid chain in various positions. In biological assays aurachins show growth inhibitory activity against numerous Gram-positive bacteria and weak antifungal activity. Aurachin C (4) and D (2) have been extensively studied as they strongly inhibit the quinol oxidation sites of Escherichia coli, that is, cytochromes bo and $b d .^{7}$
Isomers of $\mathbf{2}$ have been used for electron transfer studies to further characterize the cytochrome oxidase $b d$ from Azotobacter vinelandii. ${ }^{8}$ The different selectivities of 4 - the $N$-hydroxy derivative of 2 -and 2 toward cytochromes $b d$ and $b o$ of $E$. coli make them a unique model system to study the selectivity of these oxidases.

Compounds 1-4 were tested for antimicrobial activity against several Gram-positive and Gram-negative bacteria using a resazurinbased assay. Compounds $\mathbf{3}$ and $\mathbf{4}$ showed moderate antibacterial activity (70-89\% growth inhibition at $100 \mu \mathrm{M})$ against Staphylococcus epidermidis DSM 20044, Bacillus subtilis DSM 347 and Propionibacterium acnes DSM 1897, whereas compounds 1 and $\mathbf{2}$ were found to be inactive up to a concentration of $100 \mu \mathrm{M}$. Gram-negative bacteria, such as E. coli K12 DSM 498, Pseudomonas fluorescens NCIMB 10586, P. aeruginosa DSM 50071 and Xanthomonas campestris DSM 2405 were not susceptible to compounds $\mathbf{1 - 4}$. Interestingly, compounds 3 and $\mathbf{4}$ showed weak inhibitory activity against glycogen synthase kinase $3 \beta$ at a concentration of $10 \mu \mathrm{M}$ (19 and $22 \%$ inhibition, respectively). Measurement of the glycogen synthase kinase $3 \beta$ activity was adapted from a luminescent assay described by Baki et al. ${ }^{9}$

\section{ACKNOWLEDGEMENTS}

We gratefully acknowledge the financial support from the European Commission (project ACTAPHARM, fifth framework, QLK3-CT-2001-01783, and project ACTINOGEN, sixth framework, LSHM-CT-2004-005224), and from Bayer Schering Pharma AG (Berlin, Germany). We thank Mr A Kulik, Universität Tübingen, for assistance in fermentations.

1 Nachtigall, J., Schulz, D., Beil, W., Süssmuth, R. D. \& Fiedler, H.- P. Aranciamycin anhydride a new anthracycline-type antibiotic isolated from Streptomyces sp. Tü 6384. J. Antibiot. 63, 397-399 (2010).

2 Fiedler, H.- P. Biosynthetic capacities of actinomycetes. 1. Screening for novel secondary metabolites by HPLC and UV-visible absorbance libraries. Nat. Prod. Lett. 2, 119-128 (1993)

3 Goodfellow, M., Chun, J., Stackebrandt, E. \& Kroppenstedt, R. M. Transfer of Tsukamurella wratislaviensis Goodfellow et al. 1995 to the genus Rhodococcus as Rhodococcus wratislaviensis comb. nov. Int. J. Syst. Evol. Microbiol. 52, 749-755 (2002).

4 Kunze, B., Höfle, G. \& Reichenbach, H. The aurachins, new quinoline antibiotics from myxobacteria: production, physico-chemical and biological properties. J. Antibiot. 40, 258-265 (1987).

5 Augustiniak, H. et al. Preparation of aurachins and their use as antibiotics. Ger. Offen. 42, DE 3520229 A1 (1986).

6 Kitagawa, W. \& Tamura, T. A quinoline antibiotic from Rhodococcus erythropolis JCM 6824. J. Antibiot. 61, 680-682 (2008).

7 Meunier, B., Madgwick, S. A., Reil, E., Oettmeier, W. \& Rich, P. R. New Inhibitors of the quinol oxidation sites of bacterial cytochromes bo and bd. Biochemistry 34, 1076-1083 (1995).

8 Jünemann, S., Wrigglesworth, J. M. \& Rich, P. R. Effects of decyl-aurachin D and reversed electron transfer in cytochrome bd. Biochemistry 36, 9323-9331 (1997).

9 Baki, A., Bielik, A., Molnár, L., Szendrei, G. \& Keserü, G. M. A high throughput luminescent assay for glycogen synthase kinase-3 $\beta$ inhibitors. Assay Drug Develop. Technol. 5, 75-83 (2007). 